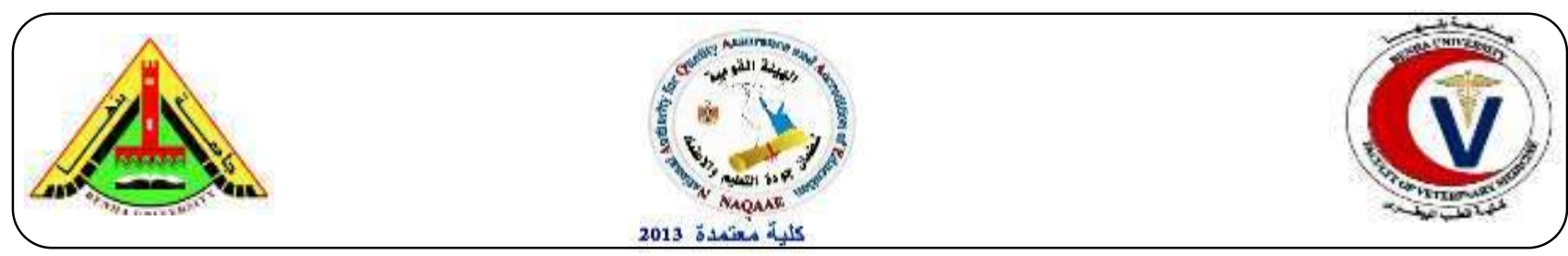

\title{
Prevalence of Mycoplasma bovis in bovine clinical mastitis milk in Egypt
}

\author{
Ashraf A. Abd El Tawab ${ }^{1}$, Fatma I. El-Hofy ${ }^{1}$, Naglaa I. Hassan ${ }^{2}$, Manar E. El-khayat ${ }^{1}$ \\ ${ }^{1}$ Department of Bacteriology, Immunology and Mycology, Faculty of Veterinary Medicine, Benha University \\ ${ }^{2}$ Department of Reproductive Diseases Research, Animal Reproduction Research Institute, Al-Haram, Giza, Egypt
}

\section{A B S T R A C T}

Bovine mastitis caused by Mycoplasma bovis represents a major problem for dairy industry all over the world. Although Mycoplasma species were identified in Egypt decades ago, the prevalence of Mycoplasma bovis mastitis is not frequently investigated. The current study was designed to monitor the prevalence of Mycoplasma bovis in clinical bovine mastitis milk in Egypt. Clinical mastitis milk samples ( $\mathrm{n}=703$ ) were collected between 2016 to 2019 from different dairy farms located in different governorates in Egypt including, Giza (227), Alexandria (357), Dakahlia (78), Buhayrah (27), Ismailia (14) and presented for Mycoplasma isolation using conventional cultural method followed by molecular identification of Mycoplasma bovis using PCR targeting mb-mp 81 gene of M. bovis. From the examined samples ( $\mathrm{n}=703)$, Sixty-three (8.96\%) were positive for Mycoplasma isolation. Among the 63 Mycoplasma isolates, 53 were identified by PCR as Mycoplasma bovis representing $84.12 \%$ of the recovered Mycoplasma isolates $(\mathrm{n}=63)$ and $7.53 \%$ from the total examined mastitis milk samples (n=703). From the 53 Mycoplasma bovis isolates, 17/227 (7.48\%) were obtained from Giza, 13/357 (3.64\%) from Alexandria, 18/78 (23.07\%) from Dakahlia, 1/27 (3.70\%) from AlBuhayrah and 4/14 (28.57\%) from Ismailia.

Keywords: Mycoplasma bovis, Mastitis, Milk, PCR, mb-mp 81, Egypt.

Received: 19 June 2019, Accepted: 7 July 2019 (http://www.bvmj.bu.edu.eg)

(BVMJ-36(2): 57-65, 2019)

\section{INTRODUCTION}

Mycoplasma bovis is one of the serious cattle pathogens threatening animal welfare and the farming industry with capability of infecting cattle in all ages (Nicholas \& Ayling, 2003). It had a worldwide distribution and associated with a variety of disease conditions, including mastitis, pneumonia, otitis media, arthritis and genital disorders (Parker et al., 2018). Indeed, Mycoplasma bovis is a main cause of mastitis problems in dairy cattle (Aebi et al., 2015). Mycoplasma bovis first record as a causative agent of sever mastitis outbreak was in 1961s in a commercial dairy herd in the USA and was named Mycoplasma agalactiae var bovis (Hale et al. 1962). Afterwards in the 1976s, Mycoplasma agalactiae var bovis was subsequently elevated to species level and named Mycoplasma bovis (Askaa and Erno, 1976). In Egypt, El-Ebeedy et al., (1985) and Eissa (1986) reported the first isolation of Mycoplasma bovis from bovine mastitis outbreaks, respectively. Since then Mycoplasma bovis, has persisted in Egyptian cattle herds. It belongs to genus Mycoplasma, 
family Mycoplasmatacae, Class Mollicutes and characterized by the cell wall lackage, low $\mathrm{G}+\mathrm{C}$ content $(23-40 \%)$ and a limited genome size of 0.58-1.4 Mbp (Parte et al., 2011; Brown et al., 2015). In vitro cultivation of Mycoplasma is difficult due to their limited biosynthetic activity; therefore, complex media supplemented with cholesterol, serum and DNA is used for the in vitro growth of Mycoplasma micro-colonies with the characteristic "fried eggs" appearance, which are visible via stereomicroscope (Razin et al., 1998; Quinn et al., 2013; Calcutt et al., 2018) Mastitis caused by Mycoplasma bovis results in economic losses from reduction in milk production, reduced quality of milk, diagnosis and treatment costs, deaths and culling losses (Kauf et al., 2007; Maunsell et al., 2011). In the USA, the financial losses triggered by Mycoplasma bovis mastitis were around \$108 million per year with morbidity rates in approximate to $70 \%$ of a herd (Rosengarten and Citti, 1999). Mycoplasma mastitis characterized by several milk changes including, watery secretion with sandy flakes, yellowish brown secretions, purulent milk with cottage cheesy appearance (Bushnell, 1984). Mycoplasma mastitis might be transmitted via several routes, including dissemination of infection during milking time, importation of infected animals from outside the herd, internal transmission from extamammary Mycoplasma infection and presence of asymptomatic carrier to mastitis (Fox et al., 2005). Since, Mycoplasma mastitis is largely incurable by antimicrobial drugs with ineffectiveness of experimental vaccines against Mycoplasma mastitis, segregation and culling of infected animals is the core of Mycoplasma mastitis control strategy (Ross, 1993; Maunsell et al., 2011 and Fox, et al., 2005). Although Mycoplasma bovis was identified in Egypt decades ago, the prevalence of Mycoplasma bovis mastitis is not frequently investigated, as Mycoplasma is overlooked in many laboratories in mastitis cases owing to the lack of specialized techniques and required facilities needed for Mycoplasma detection, in addition to the difficulty of the in-vitro cultivation of Mycoplasma. This study was designed to monitor the prevalence of Mycoplasma bovis in bovine mastitis milk in different governorates in Egypt.

Athrough bacteriological and molecular investigation of bovine mastitis milk from different dairy herds.

\section{Materials and methods}

\subsection{Collection of samples:}

A total of 703 clinical mastitis milk samples were collected from different dairy farms located in different governorates in Egypt including, Giza (227), Alexandria (357), Dakahlia (78), Buhayrah (27), Ismailia (14). Samples were collected under aseptic condition from cattle suffering from mastitis with changes in milk characters as bloody and chocolate milk with consistency ranging from watery to thick and colostrum like then submitted to Mycoplasma isolation using conventional cultural technique followed by molecular identification of Mycoplasma bovis using PCR targeting $m b-m p 81$ gene of Mycoplasma bovis.

\subsection{Isolation of Mycoplasma from mastitis milk using conventional cultural method:}

It was performed according to Nicholas et al., (2008), Hazelton et al., (2018). Mycoplasma isolation from milk samples was done by using, Mycoplasma agar (Oxoid CM0401) and broth (Oxoid CM0403) supplemented with Mycoplasma selective supplement G (Oxoid SR0059) and $0.2 \% \mathrm{w} / \mathrm{v}$ deoxyribonucleic acid sodium salt from calf thymus (Sigma-Aldrich D1501). $0.1 \mathrm{ml}$ of milk was inoculated into 5 $\mathrm{ml}$ Mycoplasma broth followed by incubation for 7 days at $37^{\circ} \mathrm{c}$ in a candle jar with elevated $\mathrm{CO}_{2}$ levels, and examined for growth daily then subculturing is done into broth and plates. 
Plates were examined using stereomicroscope to detect the characteristic fried egg colonies. Suspected samples were subcultured three times before being rejected as negative samples.

\subsection{Biochemical identification of} Mycoplasma bovis isolates recovered from examined milk samples:

It was performed according to Freundt et al. (1973), Erno and Stepkovits (1973) by application of Digitonin sensitivity test, Glucose fermentation test and Arginine hydrolysis test.

\subsection{Molecular identification of Mycoplasma} bovis isolates:

Positive culture isolates were submitted to Mycoplasma bovis specific PCR using forward $\begin{array}{llll}\text { primer } & \text { mb-mp } & 81 & \mathrm{~F}\end{array}$ 'TATTGGATCAACTGCTGGAT-3' and reverse primer mb-m 81 R 5'AGATGCTCCACTTATCTTAG -3' targeting mb-mp 81 gene with 447 bp amplicon size (Foddai et al., 2005). Reference strains Mycoplasma bovis NCTC 10131 and reference strain Mycoplasma bovigenitalium NCTC 10122 were used as control positive and control negative, respectively.

2.4.1. Extraction of DNA from Mycoplasma isolates:

Extraction of DNA from Mycoplasma isolates was done by using boiling method according to Queipo-Ortuno et al., (2007) with the following modifications; one $\mathrm{ml}$ of Mycoplasma broth culture was centrifuged at $12,000 \mathrm{rpm}$ for 10 minutes. Supernatant was discarded and pellet was washed twice by using $1 \mathrm{x}$ tris EDTA (TE) buffer at 10,000 rpm then supernatant was discarded. $100 \mu 1 \mathrm{1x}$ TE buffer was added to the pellet followed by boiling in a heat block for 20 minutes then cooling at $-20^{\circ} \mathrm{C}$ freeze for 10 minutes followed by centrifugation at $12,000 \mathrm{rpm}$ for 10 minutes then supernatant was collected into a new microcentrifuge tube and stored at $-20^{\circ} \mathrm{C}$ for use.
2.4.2 Amplification and cycling protocol of PCR:

It was performed according to specific author Foddai et al., (2005) and Dream Taq green master mix (Thermo scientific ${ }^{\mathrm{TM}}$ ) kit code No. K1081. PCR amplification was carried out on a T100 thermal cycler (Bio-rad) in a total reaction volume of $20 \mu \mathrm{l}$ containing $10 \mu \mathrm{l}$ dream Taq green master mix (Thermo scientific $^{\mathrm{TM}}$, K1081), $0.5 \mu 1$ of each forward and reverse primers, $5 \mu \mathrm{l}$ Nuclease free molecular biology grade water and $4 \mu \mathrm{l}$ test DNA at thermal profile of 1 cycle of $94^{\circ} \mathrm{C}$ for $4 \mathrm{~min} ; 30$ cycles of $94^{\circ} \mathrm{C}$ for $60 \mathrm{~s}, 54^{\circ} \mathrm{C}$ for 60 $\mathrm{s}, 72^{\circ} \mathrm{C}$ for $60 \mathrm{~s} ; 1$ cycle of $72^{\circ} \mathrm{C}$ for $10 \mathrm{~min}$; and a final hold at $4^{\circ} \mathrm{C}$ until stop.

\subsubsection{Detection of PCR products:}

It was performed according to Sambrook et al., (1989). Amplicons were detected by electrophoresis on $2 \%$ agarose gel stained by ethidium bromide and examined by gel documentation system (Bio-Rad).

\section{RESULTS}

\subsection{Isolation of Mycoplasma from Mastitis milk samples:}

Sixty-three Mycoplasma isolates were recovered from 703 mastitis milk samples in a percentage of $8.96 \%$ (Figure 1) with the isolates showing the characteristic fried egg colonies on Mycoplasma agar (Figure 2). Out of the 63 Mycoplasma isolates, 23/227 $(10.13 \%)$ were obtained from Giza, 17/357 (4.76\%) from Alexandria, 18/78 (23.07\%) from Dakahlia, $1 / 27$ (3.70\%) from AlBuhayrah and 4/14 (28.57\%) from Ismailia (Table 1, Figure 3).

\subsection{Biochemical identification of Mycoplasma isolates recovered from mastitis milk samples:}

All examined Mycoplasma isolates were digitonin sensitive with $>5 \mathrm{~mm}$ zones of growth inhibition in digitonin disc diffusion assay. Furthermore, Isolates were negative for 
glucose fermentation test and arginine hydrolysis test.

\subsection{Molecular identification of Mycoplasma bovis by PCR targeting mb-mp 81 gene:}

Out of the 63 Mycoplasma isolates, 53 were identified as Mycoplasma bovis by PCR targeting Mycoplasma bovis mb-mp 81 gene representing $84.12 \%$ of Mycoplasma isolates $(n=63)$ and $7.53 \%$ from the total examined mastitis milk samples ( $n=703$ ) (Figure 4).
3.4. Incidence of Mycoplasma bovis from different governorates in Egypt:

Fifty-three Mycoplasma bovis were recovered from 703 clinical mastitis milk samples collected from different dairy farms located in different governorates in Egypt as the following, 17/227 (7.48\%) were obtained from Giza, 13/357 (3.64\%) from Alexandria, 18/78 $(23.07 \%)$ from Dakahlia, $1 / 27(3.70 \%)$ from Al-Buhayrah and 4/14 (28.57\%) from Ismailia (Table 2, Figure 5).

Table 1: Incidence of Mycoplasma spp. recovered from bovine mastitis milk samples from different governorates in Egypt.

\begin{tabular}{|c|c|c|c|}
\hline Governorate & Number of samples & $\begin{array}{c}\text { Number of positive } \\
\text { samples }\end{array}$ & $\begin{array}{c}\text { Percentage of positive } \\
\text { samples* }\end{array}$ \\
\hline Giza & 227 & 23 & 10.13 \\
\hline Alexandria & 357 & 17 & 4.76 \\
\hline Dakahlia & 78 & 18 & 23.07 \\
\hline Buhayrah & 27 & 1 & 3.70 \\
\hline Ismailia & 14 & 4 & 28.57 \\
\hline Total & 703 & 63 & $8.96 * *$ \\
\hline \multicolumn{4}{|c|}{$\begin{array}{l}\text { * Percentage in relation to number of examined samples in each row. } \\
\text { **Percentage in relation to Total number of examined samples }(\mathrm{n}=703) \text {. } \\
\text { Table } 2 \text { : Incidence of Mycoplasma bovis isolated from bovine mastitis milk samples from different } \\
\text { governorates in Egypt. }\end{array}$} \\
\hline Governorate & Number of samples & $\begin{array}{l}\text { Number of positive } \\
\text { samples }\end{array}$ & $\begin{array}{l}\text { Percentage of positive } \\
\text { samples* }\end{array}$ \\
\hline Giza & 227 & 17 & 7.48 \\
\hline Alexandria & 357 & 13 & 3.64 \\
\hline Dakahlia & 78 & 18 & 23.07 \\
\hline Buhayrah & 27 & 1 & 3.70 \\
\hline Ismailia & 14 & 4 & 28.57 \\
\hline Total & 703 & 53 & $7.53 * *$ \\
\hline
\end{tabular}




\section{Mycoplasma isolation from bovine mastitis milk samples}

63

640
Negative samples for Mycoplasma isolation

- Positive samples for

Mycoplasma isolation

Fig.1. Incidence of Mycoplasma spp. isolated from bovine mastitis milk samples in Egypt.

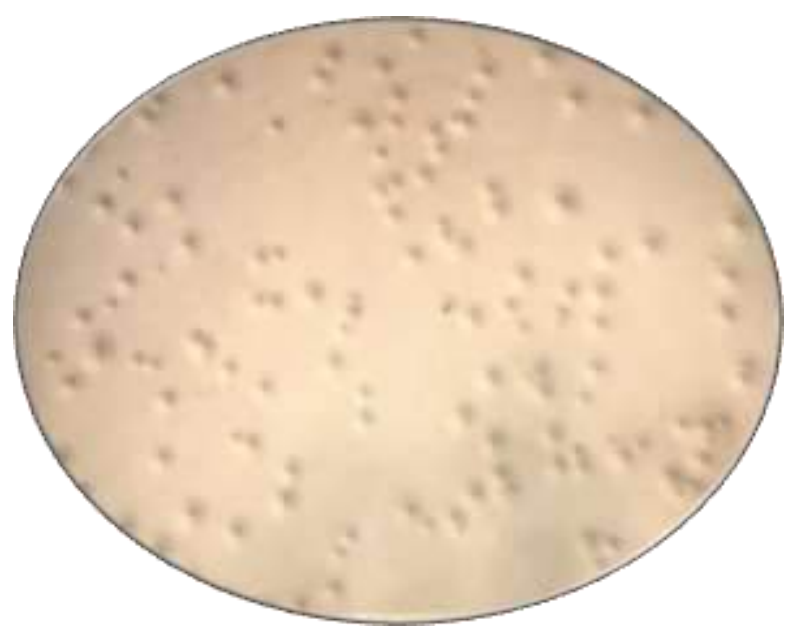

Fig.2. Fried egg appearance of Mycoplasma colonies on Mycoplasma agar.

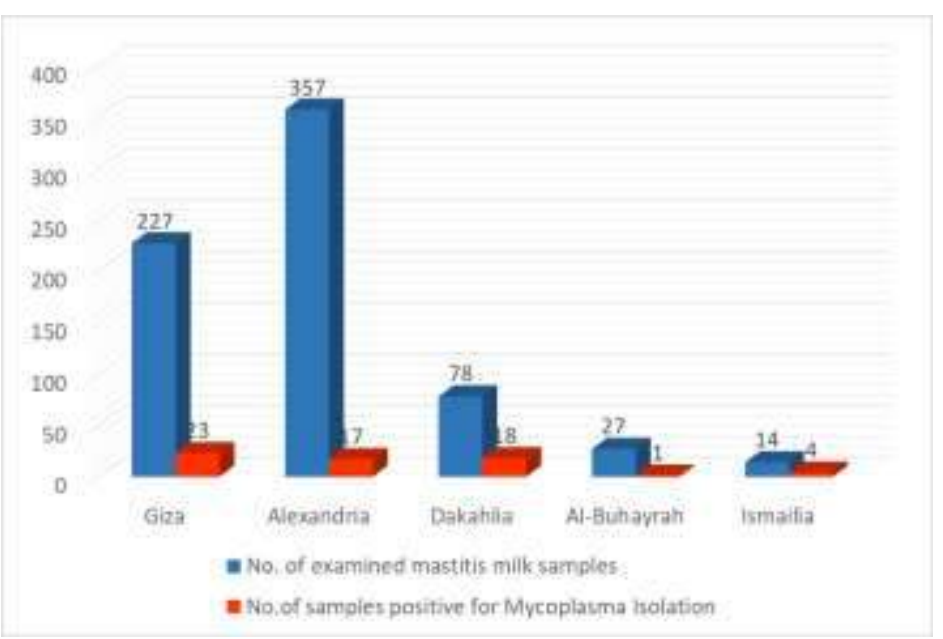

Fig.3. Incidence of Mycoplasma spp isolated from bovine mastitis milk samples from different governorates in Egypt. 


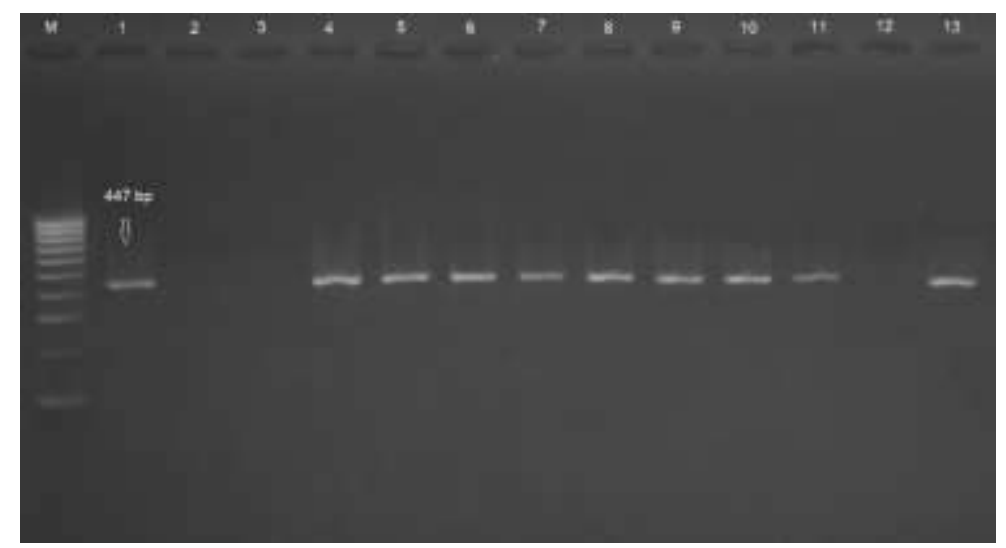

Fig.4. Agarose gel electrophoresis of PCR amplified products of Mycoplasma bovis mb-mp 81 gene from isolates. Lane M: Marker (GeneRuler100 bp DNA ladder, Thermo scientific ${ }^{\mathrm{TM}}$ ), Lane 1: Positive control (Mycoplasma bovis NCTC 10131), Lane 2: negative control (Mycoplasma bovigenitalium NCTC 10122), Lanes 4-11, 13: Positive for $m b-m p 81$ gene with 447 bp amplicon, lanes 3, 12: negative $m b$-mp81.

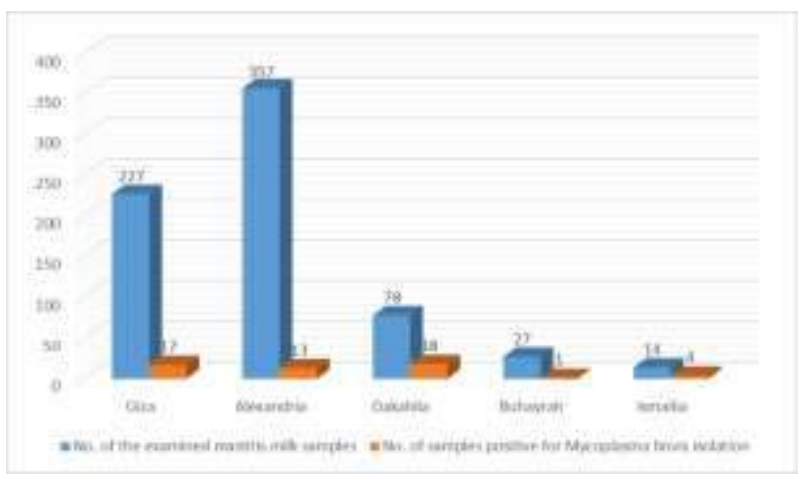

Fig.5. Incidence of Mycoplasma spp isolated from bovine mastitis milk samples from different governorates in Egypt.

\section{DISCUSSION}

Mastitis, the dairy cattle's most costly disease, remains an on-going issue for dairy industry (Barkema et al., 2009). Many Mycoplasma species exist but few are associated with mastitis, with more than $50 \%$ of Mycoplasma mastitis cases, caused by Mycoplasma bovis (Wen et al., 2019). In the current study, we monitor the prevalence of Mycoplasma bovis in bovine mastitis milk in Egypt through bacteriological and molecular investigation of bovine clinical mastitis milk from different dairy herds in different governorates in Egypt. The results revealed the recovery of sixty-three Mycoplasma isolates out of the $703(8.96 \%)$ examined clinical mastitis milk with colonies giving the characteristic "fried egg appearance" which is attributed to the embedment of the central portion of the colony into the agar with a surrounding zone of surface growth (McVey et al., 2013). In addition, isolates were positive for digitonin sensitivity test with $\geq 5$ zones of growth inhibition. This is attributed the interaction of Digitonin with sterol forming a complex, which interrupts the exogenous uptake of sterol by Mycoplasma, and so, killing of Mycoplasma (Boonyayatra 2012) .Out of the sixty-three Mycoplasma isolates, 53 were identified as Mycoplasma bovis by PCR targeting mb-mp 81 gene of Mycoplasma bovis adapted from (Foddai et al., 2005) in a percentage of $7.53 \%$. From the 53 Mycoplasma bovis isolates, 17/227 (7.48\%) were obtained from Giza, 13/357 (3.64\%) from Alexandria, 18/78 (23.07\%) from Dakahlia, $1 / 27(3.70 \%)$ from Al-Buhayrah and 4/14 
(28.57\%) from Ismailia. Comparing with other results, Al-Farha et al., (2017) reported slightly lower percentage 6.2\% in South Australia with a percentage of $6.2 \%$. While Arcangioli et al., (2011) and Surýnek et al., 2016 reported that Mycoplasma bovis was not isolated from the Southeast of France and the Czech Republic, respectively. Filioussis et al., 2007 reported the isolation of Mycoplasma bovis in a slightly higher percentage $8.2 \%$ in Northern Greek. While Karahan et al., (2010) reported significantly higher percentage $21.1 \%$ from eastern Turkey. In Egypt, Gad et al., (1987), Abd El-Rahman and Saad (1993), Hassan and El Rashidy (2002), Hassan and Essmail (2004), Darwish et al., (2015) reported higher percentages of Mycoplasma bovis isolation from clinical mastitis milk; 70.83\%, $14.37 \%$, $42.35 \%, 52 \%$ and $11.68 \%$ respectively. While El-Gamal et al., (1999) obtained lower percentage $2.7 \%$. This variation in the prevalence of Mycoplasma bovis upon local and global levels may be attributed to several causes, including herd sizes as explained by Arcangioli et al., 2011; this previous publication attributed the sporadic nature of Mycoplasma mastitis in France to the small size of the herds together with the management practices applied within the herd. In addition, Mycoplasma can be transmitted by infected milk, milk clusters or milkers' hands (Calcutt et al., 2018), specially that infected animals might turn to a symptomatic shedders of Mycoplasma without showing any clinical signs. Moreover, the introduction of new animals from outside of the herd serves as a major risk factor for occurrence of Mycoplasma mastitis outbreaks (Punyapornwithaya et al., 2010).

\section{CONCLUSION}

Mycoplasma mastitis caused by Mycoplasma bovis is a perilous problem for dairy industry throughout the world. Our research findings disclosed that Mycoplasma bovis mastitis is quite common in Egypt. Accordingly, Largescale epidemiological investigations should frequently be carried out to withstand the prevalence of the Mycoplasma bovis mastitis infection in Egypt. In addition, restrict prevention and control strategies should be applied combined routine bacteriological examination for Mycoplasma spp. for the newly purchased animals prior to their introduction to the herd.

\section{REFERENCES}

Abd El-Rahman, F. and Saad, M. (1993). Incidence of clinical mastitis associated with Mycoplasma infection. Vet. Med. J., 41(2): p 67-69.

Aebi, M., van den Borne, B. H. P., Raemy, A., Steiner, A., Pilo, P., and Bodmer, M. (2015). Mycoplasma bovis infections in Swiss dairy cattle: A clinical investigation. Acta Veterinaria Scandinavica, 57, 10 . https://d oi.org/10.1186/s13028-015-0099-x.

Al-Farha, A., Hemmatzadeh, F., Khazandi, M., Hoare, A., and Petrovski, K. (2017). Evaluation of effects of Mycoplasma mastitis on milk composition in dairy cattle from South Australia. BMC Veterinary Research, 13: 351.

Arcangioli, M., Chazel, M., Sellal, E., Botrel, M., Bézille, P., Poumarat, F., Calavas, D. and Le Grand, D. (2011). Prevalence of Mycoplasma bovis udder infection in dairy cattle: Preliminary field investigation in Southeast France. New Zealand Veterinary Journal, 59(2), 7578.

doi: $10.1080 / 00480169.2011 .552856$

Askaa, G., and Erno, H. (1976). NOTE: Elevation of Mycoplasma agalactiae subsp. bovis to Species Rank: Mycoplasma bovis (Hale et al.) comb. Nov. International Journal of Systematic Bacteriology, 26(3), 323325.

Barkema, H.W., Green, M.J., Bradley, A.J. and Zadoks R.N. (2009). Invited review: The role of contagious disease in udder health. J Dairy Sci. 2009 Oct; 
92(10):4717-29. doi: 10.3168/jds.20092347.

Boonyayatra, S., Fox, L. K., Gay, J. M., Sawant, A., and Besser, T. E. (2012). Discrimination between Mycoplasma and Acholeplasma species of bovine origin using digitonin disc diffusion assay, nisin disc diffusion assay, and conventional polymerase chain reaction. Journal of Veterinary Diagnostic Investigation, 24(1), 7-13.

Brown, D. R., May, M., Bradbury, J. M. and Johansson, K. E. (2015). Mollicutes. Bergey's Manual of Systematics of Archaea and Bacteria. P 1-8.

Bushnell, R. B. (1984). Mycoplasma Mastitis. Veterinary Clinics of North America: Large Animal Practice, 6(2), 301-312.

Calcutt, M. J., Lysnyansky, I., Sachse, K., Fox, L. K., Nicholas, R. A. J., and Ayling, R. D. (2018). Gap analysis of Mycoplasma bovis disease, diagnosis and control: An aid to identify future development requirements. Transboundary and Emerging Diseases, 65, 91-109.

Darwish, S., Zeineldeen, D. Hassan, N. and El Seedy, F. (2015). Evaluation of conventional PCR assays for molecular diagnosis of Mycoplasma infection versus traditional diagnostic methods. Journal of Egyptian veterinary association 75(1): p 139-156.

Eissa, S.I., (1986). Some studies on Mycoplasma mastitis in cattle and buffaloes in Egypt. Ph.D. thesis, Faculty of Veterinary Medicine, Alexandria University, Egypt.

El-Ebeedy, A.A., Gad, A.S., Rashwan, Amal, Mostafa, A., El-Ahl, S.S., Esmail, S. and Allam, N.M. (1985). Isolation of Mycoplasma bovis from an outbreak of bovine mastitis in Egypt. J. Egypt. Vet. Med. Assoc., 45, 1, 247 - 253.

El-Gamal, A., El-Gmiey, S., Abdel-Khalek, A. and Hatab, M. (1999). Bacterial spp. Isolated from Friesian mastitic cows problems and their antibiotic sensitivity pattern. Zag. Vet. J. 27(2): p 86-92.

Erno, H., and Stipkovits, L. (1973). Cultural and biochemical properties of Acholeplasma and Mycoplasma strains of cattle origin. Acta Microbiologica
Academiae Scientiarum Hungaricae, 20(4), 305-315.

Filioussis, G., Christodoulopoulos, G., Thatcher, A., Petridou, V., and BourtziChatzopoulou, E. (2007). Isolation of Mycoplasma bovis from bovine clinical mastitis cases in Northern Greece. The Veterinary Journal, 173(1), 215-218. doi:10.1016/j.tvj1.2005.08.001

Foddai, A., Idini, G., Fusco, M., Rosa, N., de la Fe, C., Zinellu, S., Corona, L. and Tola, S. (2005). Rapid differential diagnosis of Mycoplasma agalactiae and Mycoplasma bovis based on a multiplex-PCR and a PCR-RFLP. Molecular and Cellular Probes, 19(3), 207-212.

Fox, L.K., Kirk, J.H. and Britten A. (2005) Mycoplasma Mastitis: A Review of Transmission and Control. J. Vet. Med. B 52, 153-160.

Freundt, E. A., Andrews, B. E., Erno, H., Kunze, M. and Black, F. T. (1973). The sensitivity of Mycoplasmatales to sodium-polyanethol-sulfonate and digitonin. Zentralbl Bakteriol Orig A. 225(1):104-12.

Gad, A., El-Balkimi, F., El-Shennawy, M., Eissa, S., Rashwan, A. and El-Shabiny, L. (1987). Serological studies on Mycoplasma mastitis. Alex. J. Vet. Sci., 3(1): 335-344.

Hale, H. H., Helmboldt, C. F., Plastridge, W. N. and Stula, E. F. (1962). Bovine mastitis caused by Mycoplasma species. Cornell Veterinarian, 52, 582-591.

Hassan, N. and El Rashidy, A. (2002) Rapid diagnosis of Mycoplasmal mastitis using Dot-ELISA technique. Journal of the Egyptian veterinary association 62(4): p 235-248.

Hassan, N. and Essmail, M. (2004). An outbreak of Mycoplasmal mastitis in a dairy herd: isolation of $M$. bovis and the pathological findings in the udder and the lung of infected cattle. Journal of the Egyptian veterinary association 64(2): p 271-288.

Hazelton, M. S., Sheehy, P. A., Bosward, K. L., Parker, A. M., Morton, J. M., Dwyer, C. J., Niven, P. G. and House, J. K. (2018). Short communication: Shedding of 
Mycoplasma bovis and antibody responses in cows recently diagnosed with clinical infection. J. Dairy Sci, 101(1), 584-589. doi:10.3168/jds.201713512

Karahan, M., Kalin, R., Atil, E. and Cetinkaya, B. (2010). Detection of Mycoplasma bovis in cattle with mastitis and respiratory problems in eastern Turkey. Veterinary Record, 166(26), 827-829

Kauf, A. C. W., Rosenbusch, R. F., Paape, M. J., and Bannermann, D. D. (2007). Innate immune response to intramammary Mycoplasma bovis infection. Journal of Dairy Science, 90, 3336-3348. https://doi.org/10. 3168/jds.2007-0058

Maunsell, F. P., Woolums, A. R., Francoz, D., Rosenbusch, R. F., Step, D. L., Wilson, D. J., \& Janzen, E. D. (2011). Mycoplasma bovis infections in cattle. Journal of Veterinary Internal Medicine, 25 , $772-783$.

https://doi.org/10.1111/j.19391676.2011.0750.x

McVey, D.S., Kennedy, M. and Chengappa, M.M. (2013). Veterinary Microbiology. Third ed. Hoboken: Wiley.

Nicholas, R. and Ayling R. (2003): Review, Mycoplasma bovis: disease, diagnosis, and control. Veterinary Science 74,105112.

Nicholas, R., Ayling, R. and McAuliffe, L. (2008) Mycoplasma Diseases of Ruminants. Isolation and growth of Mycoplasmas from ruminants; pp. 3-14. CABI, UK. 239 pages.

Parker, A. M., Sheehy, P. A., Hazelton, M. S., Bosward, K. L., and House, J. K. (2018). A review of Mycoplasma diagnostics in cattle. Journal of Veterinary Internal Medicine, 32(3), 1241-1252.

Parte, A., Krieg, N.R. and Ludwig, W. (2011) Bergey's Manual of Systematic Bacteriology. New York, NY: Springer New York.

Punyapornwithaya, V., Fox, L. K., Hancock, D. D., Gay, J. M. and Alldredge, J. R. (2010). Association between an outbreak strain causing Mycoplasma bovis mastitis and its asymptomatic carriage in the herd: A case study from
Idaho, USA. Preventive Veterinary Medicine, 93, 66 - 70 .

Queipo-Ortuno, M. I., De Dios Colmenero, J., Macias, M., Bravo, M. J. and Morata, P. (2007). Preparation of Bacterial DNA Template by Boiling and Effect of Immunoglobulin $G$ as an Inhibitor in Real-Time PCR for Serum Samples from Patients with Brucellosis. Clinical and Vaccine Immunology, 15(2), 293296.

Quinn, P.J., Markey, B.K., Leonard, F.C., Fanning, S. and Maguire, D. (2013) Veterinary Microbiology and Microbial Disease. Second ed. Hoboken: Wiley.

Razin, S.; Yogev, D. and Naot, Y. (1998). Molecular biology and pathogenicity of Mycoplasmas. Microbiology and molecular biology reviews, 62 (4): $p$ 1094-1156.

Rosengarten, R. and Citti, C. (1999). The role of ruminant Mycoplasmas in systemic infection. In: Stipkovits, L., Rosengarten, R. and Frey, J. (Eds.), Mycoplasmas of ruminants: pathogenicity, diagnostics, epidemiology and molecular genetics, vol. 3. European Commission, Brussels, ISBN 92-828-5222-9, pp. 14-17.

Ross, R.F. (1993). Mycoplasmas-animal pathogens. In: Kahane, I. and Adoni, A. (Eds.), Rapid diagnosis of Mycoplasmas. Plenum Press, New York, USA, ISBN 978-1-4615-2478-6, pp. 69-110.

Sambrook, J., Fritsch, E.F. and Maniatis, T (1989): Molecular cloning. A laboratory manual. Second edition, Cold spring Harbor Laboratory press, New York.

Surýnek, J., Vrtková, I. and Knoll, A. (2016) Mycoplasma bovis was not detected in milk from dairy cattle in the Czech Republic. Acta universitatis agriculturae ET silviculturae mendelianae brunensis, vol 64 (19): 165-168

Wen, J., Zhang, J., and Hao, Y. (2019). The status of Mycoplasma bovis infection in clinical mastitis cases in China. International Journal of Dairy Technology. doi:10.1111/1471307.12602 . 